\title{
A conversation with John T. Potts Jr.
}

$\mathrm{M}$ uch of our current understanding of calcium metabolism rests in large part on a series of discoveries made by John T. Potts Jr. of the Massachusetts General Hospital. Potts (Figure 1) is an internationally recognized authority on calcium metabolism and parathyroid hormone (PTH) in particular. In addition to his research, he carried an enormous leadership role, serving as both Chairman of Medicine and Physician in Chief of the MGH between 1981 and 1996. The full interview, with many more stories about working with Berson and Yalow, his approach to leading the MGH and what has changed over his 56 years there, can be seen on the JCI website, http://www.jci.org/kiosk/cgm.

JCI: Can you tell us about where you grew up and about your parents?

Potts: I grew up in the small town of Moorestown, New Jersey, which is in the suburbs of Philadelphia. My father was a florist, and his father also. My mother was the one who had the vision that maybe I would become a physician, and I didn't have a very, you might say, focused career ambition. It just seemed like a nice idea, and I knew some nice doctors. I went to school at La Salle University and then University of Pennsylvania for medical school.

When I was starting medical school I thought I might go into general practice and return to the Moorestown area, which I'm sure was my mother's dream. But in medical school, when I began to see patients on the medical service in the third year, I became very interested in what's behind the diseases we see and, if we knew more, could we do a better job? And then, I became more interested in science; I really never did any previously. When I finally got this impulse, I wanted to go to the MGH, which was then the hot spot.

JCI: What made you focus on endocrinology and mineral biology?

Potts: One of the things that I noticed was endocrine homeostasis, and in particular what caught my eye was parathyroid hormone; it's the sensitive thermostat for minute-to-minute regulation of calcium. There was a wonderful surgeon at Penn named Brooke Roberts who I worked with on a patient with hyperparathyroidism and a disorder of magnesium metabolism with tetany. We got the mechanism wrong but we published a paper in 1958, and it really got me thinking about parathyroid hormone and calcium metabolism. Then I went to the MGH, which was the center of research on metabolic disease and calcium disorders in particular, with the great Fuller Albright, who had just been incapacitated by a stroke a few months before I arrived as an intern. I found myself in an environment that was very stimulating. The chief resident around that time was a remarkable man who's been celebrated by one of your earlier interviews, Holly Smith. The department chair was Walter Bauer. He was an inspiration, and loved to find people that he thought had talent, but I don't think he thought of me having much.

After a few years, it was time to decide what to do next and there was the opportunity of going to the NIH under the doctor draft, which most of us didn't understand anything about. What I wanted was to go to the NIH because that's where you could learn to do science seriously.

JCI: Is this when you ground your interest in doing research?

Potts: That's right. It began in medical school. It was reinforced by my time at the MGH filled with people who were models of how to do scientific investigation. I brought an interest in parathyroid hormone, a rather humble molecule at that point. It was one of the last hormones of the classic type to be recognized and it doesn't even have its own name; it's named for the thyroid gland that it's next to. But it was clear that it played an important role in homeostasis of calcium. I decided to work with Chris Anfinsen, a wonderful man who later won the Nobel Prize despite people like me wandering through this place, and we learned how to do protein chemistry. And then, Gerald Auerbach had, just before coming to the NIH, made a great breakthrough with parathyroid hormone, isolating it in a form that didn't produce it in pieces so you had a chance to isolate it. I had the protein chemistry; he had the biology. We teamed up across two different institutes and worked together for over a decade.

JCI: You went on to elucidate the complete amino-acid sequence of the bovine PTH.

Potts: Yes, that was a very challenging operation. My colleagues thought I was clearly crazy to work on a project of that magnitude. That was when protein structures were just being worked out. Frederick
Sanger had done insulin, which was plentiful in the pancreas of cows, but parathyroid hormone was from a little gland and it was very laborious to purify it. The methods then were rather laborious compared to the great skills of molecular biology today, where you can deduce the structure of a protein through the genomic information without ever actually isolating it. They didn't have that then. Molecular biology didn't come into full flower until the middle of the 70s, so I had to do it the oldfashioned way.

JCI: You also took on the isolation and characterization of porcine, bovine, ovine, and salmon calcitonin, which has opposing effects to PTH.

Potts: Some people approached us because by then we had a reputation for being able to do protein structure, and it seemed to us to be the yin and yang of the story. We figured we might as well work at it as we had good quantities of material. It turns out that calcitonin probably isn't very important in human physiology. At least if it is, we've all missed it because people who lose calcitonin by total thyroidectomy are fine. It is medically useful and was used in the therapy of Paget's disease and we had a good time with it, but we went back to our work on parathyroid hormone pretty earnestly because we knew it was biologically important.

JCI: After nine years at the NIH that were very productive, you landed back at $\mathrm{MGH}$ as Head of the Endocrine Division, and then in 1981, you moved up to take on the role of Chairman of Medicine. How did you balance that leadership role with a rigorous laboratory regimen as well?

Potts: Well, I was fortunate. I had wonderful colleagues who had grown up with me in the Endocrine Unit between ' 68 and '81 and they seemed to tolerate and want my presence, so I just blocked out time as Chairman of Medicine three or four days a week. I would just leave the office and go to my research group. Many Chairs of Medicine had national duties on administrative boards, but I made the deliberate decision to not do as much in that area and instead protect my research time. Since we were very interactive as a group, I wasn't directing postdoctoral fellows, I was working with my senior colleagues and we would be sharing information. We'd have three 


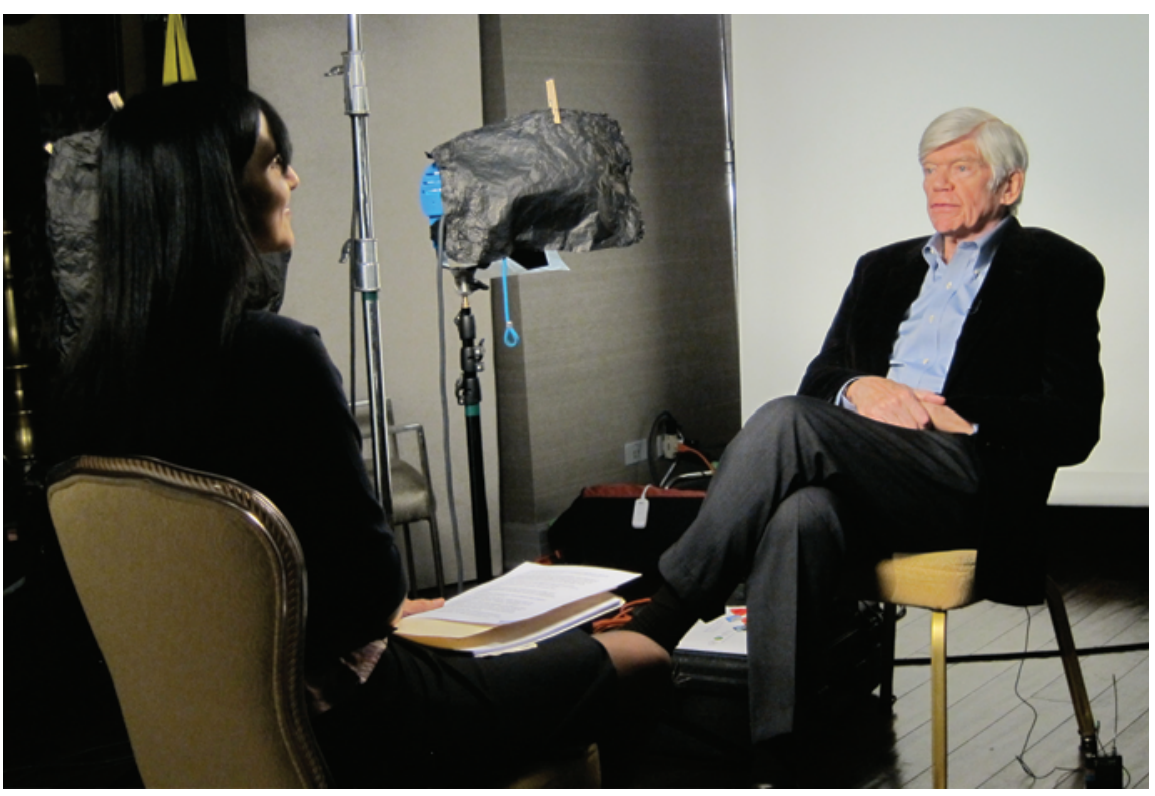

Figure 1

Ushma S. Neill interviewing John T. Potts Jr. on April 27, 2013. Image credit: Karen Guth.

or four work conferences a week in which people would present what was going on they'd look at the challenges, where should we go next, what's wrong with this, how should we go?

I don't know that I changed anything; I maybe emphasized certain things. As Chairman of Medicine, I started an effort to bring in more underrepresented minorities. We tried to particularly shepherd their career development; I learned a lot about the issues for underrepresented minorities through getting to know them, both men and women. I also formed a little group called the MGH Society of Research Fellows, with about 60 members altogether over the years. I would help them to find good laboratories to go to - often they would be there for several years, and they'd want to go into a basic lab. As I had good connections with people at MIT and Harvard, I did some matchmaking.

JCI: Sounds like you took your role as a mentor and protector seriously. What messages did you try to reinforce to your trainees?

Potts: For young people, we want to encourage them to stay in this marvelous field of basic biomedical research because, despite all the stresses and strains, opportunity and prospects for growth could never have been greater - at least in earlier years. There is still opportunity, and we have to find ways in stabilizing and encouraging the younger people even though research support is more difficult now.

The way careers develop, looked at in retrospect, seem very linear and straightforward. But it's really an erratic step-bystep movement. It always looks very clear at the end, but not when you're doing it, and that's important for young people to understand. Just work hard, pick a good problem, and get some good help from people around you. Don't be afraid to share data, and you'll get somewhere.

JCI: Is that how you felt when you were going through it? Because in looking at your CV, it's quite a linear trajectory of picking off problem after problem, whether it was calcitonin or PTH or mechanisms of action of PTH.

Potts: Well, once we were working in the field, it was clear where the next question in that field might be, but why did I work on parathyroid hormones as compared to something else? Why did I become a physician scientist instead of something else? Those are things that are much more complex. What I meant was, you know what the question is that you want to answer next. That's logical. But you want to avoid giving young people the idea that they have to see a clear path from where they are to where they're going to be 40 years from now. It's not as simple as that. And being opportunistic, hard working, and collaborative are the key things to get where you want to be. I had collaborators my entire career who were wonderful. If you celebrate young peo- ple around you, they feel like they can grow, then they like being around you, and you like being around them. A rigid, controlling approach doesn't build collaborative networks. Those are critical, particularly in today's science. You have to be interactive and supportive. MGH is like that. People celebrate one another's excellence rather than being threatened by it.

JCI: Speaking of looking through your $\mathrm{CV}$, I noted one item that was rather unusual. In 1980, you were on the US-USSR Joint Working Group on Space Medicine. What did that entail?

Potts: At the time, the Russians had claimed they had solved the problem of weight loss in space, but they wouldn't tell NASA what it was. So, NASA wanted to bring a scientist from the US who was well thought of already by that time as bait to get the Russians to talk. I had briefings from the State Department on how I was to comport myself. There were people who wanted me to smuggle things in for the refuseniks but I demurred because I was afraid that I might jeopardize the mission.

When we were in Russia we had a wonderful time; our hosts were wonderful and genial, but in the background was the KGB trying to embarrass the delegates. There were some harrowing experiences - they tried to trap us into doing awkward, stupid things that involved beautiful women showing up and jumping in our laps. But, we were very noble and went straight ahead without getting distracted. They had television monitors in every room. I thought this was sick, but we got through it fine.

We learned the answer to the scientific question: the answer was there was no secret to find. They had poor measurement techniques, so they did measurements before and after the flight. The error was such that you could make no conclusions. There was no secret. It was a very nice experience, but it was certainly bizarre.

JCI: If you had to do it all over again, would you have chosen a different vocation?

Potts: It's hard to say. As I described to you at the beginning, I had this idea I would be a doctor, and so I followed it. I can hypothesize what might have happened but I didn't have a burning and driven choice at the beginning. I didn't really know what I was doing. I just sort of followed my nose and it all happened. I suppose, if I wasn't doing medicine, maybe I would like teaching English literature.

\section{Ushma S. Neill}

